\title{
PENGARUH LIKUIDITAS TERHADAP KINERJA KEUANGAN DI MODERASI PROFITABILITAS PADA PERUSAHAAN JASA SUB SEKTOR PROPERTY \& REAL ESTATE YANG TERDAFTAR DI BURSA EFEK INDONESIA
}

\author{
Anjela 1)*, Eli Hasmin 2), Herman Sjahruddin' ${ }^{3)}$. \\ 1) Manajemen Keuangan, Sekolah Tinggi Ilmu Ekonomi Makassar \\ Email:angelasuyuti52@gmail.com \\ 2) Manajemen Keuangan, Sekolah Tinggi Ilmu Ekonomi Makassar \\ 3) Manajemen Keuangan, Sekolah Tinggi Ilmu Ekonomi Makassar
}

\begin{abstract}
Penelitian ini bertujuan untuk mengetahui pengaruh Likuiditas terhadap Kinerja keuangan dimoderasi Profitabilitas. Penelitian ini menggunakan data pada Perusahaan Property dan Real estate yang terdaftar di Bursa Efek Indonesia periode 2015 - 2017. Penentuan sampel dalam penelitian ini menggunakan metode purposive sampling, dengan jumlah pengamatan sebanyak 16 sampel penelitian. Teknik analisis data yang digunakan adalah Moderated Regression Analysis (MRA). Berdasarkan hasil analisis regresi moderasi bahwa Likuiditas berpengaruh negative dan signifikan terhadap kinerja keuangan dan Profitabilitas yang diproksikan dengan Return On Asset mampu memoderasi Likuiditas terhadap kinerja keuangan.
\end{abstract}

Keywords: Likuiditas, Profitabilitas, Kinerja Keuangan. 


\section{PENDAHULUAN}

Pertumbuhan perekonomian suatu negara dapat dilihat dari perkembangan dunia usaha yang ada di negara tersebut, termasuk Indonesia yang memiliki berbagai macam industri, baik bersekala kecil maupun besar. Salah satu industri yang menjadi indikator untuk menganalisis pertumbuhan perekonomian suatu negara adalah sektor real estate dan property. Perkembangan industri real estate dan property akan selalu berkembang pesat dan meningkat setiap tahunya, itu dikarenakan tanah memiliki ketersediaan yang bersifat tetap sedangkan setiap tahun jumlah penduduk Indonesia semakin meningkat.

Teori yang digunkan dalam penelitian ini mengacu pada teori sinyal (Signalling Theory) Signalling theory merupakan suatu tindakan yang diambil perusahaan untuk memberikan petunjuk bagi investor tentang bagaimana manajemen memandang prospek perusahaan (Brigham, 2008). Sinyal ini berupa informasi mengenai apa yang sudah dilakukan oleh manajemen untuk merealisasikan keinginan pemilik. Sinyal dapat berupa informasi yang menyatakan bahwa perusahaan tersebut lebih baik dari pada perusahaan lain (Fenandar, 2012). Informasi yang dikeluarkan oleh perusahaan merupakan hal yang penting, karena pengaruhnya terhadap keputusan investasi pihak diluar perusahaan. Informasi tersebut penting bagi investor karena informasi pada hakekatnya menyajikan keterangan berupa catatan atau gambaran tentang keadaan masa lalu, saat ini, maupun masa yang akan datang bagi kelangsungan hidup perusahaan dan bagaimana efeknya pada perusahaan.

Berdasarkan hasil penelitian terdahulu yang dilakukan Mahardhika \& Marbun, 2016; Ngendakusuma, dkk, 2015) mengemukakan bahwa current ratio memiliki hubungan yang positif dan signifikan terhadap kinerja keuangan perusahaan yang dilihat dari prifitabilitas (ROA). Sedangkan Rachmawati (2016) memperoleh hasil yang sebaliknya yaitu negative dan signifikan. Menurut Kasmir (2008) Apabila perusahaan memiliki current ratio rendah atau berada pada angka dibawah $200 \%$ dapat dikatakan bahwa perusahaan kekurangan modal untuk memenuhi utang jangka pendeknya, tetapi jika current ratio berada pada angka $200 \%$ atau lebih maka perusahaan sudah di anggap memiliki kondisi yang cukup baik dan mampu memenuhi utang jangka pendeknya. Berdsarkan penelitian yang dilakukan Lusi Mirnawati, Lestari Wuryanti dan Bambang Purwanto(2015) bahwa profitabilitas berpengaruh signifikan terhadap kinerja keuangan. Sedangakn hasil penelitian Agus Sukarno (2006) bahwa return on asset berpengaruh negative dan signifikan terhadap kinerja keuangan dan dapat menurunkan kinerja keuangan.

Kondisi perusahaan Property dan Real Estate beberapa tahun terakhir mengalami perkembangan yang pesat setiap tahun dan merupakan kelompok sektor yang paling banyak terdaftar di Bursa Efek Indonesia (BEI) selain perbankan serta merupakan salah satu investasi yang diminati investor dimana investasi di sektor ini merupakan investasi jangka panjang dan properti merupakan aktiva multiguna yang dapat digunakan oleh perusahaan sebagai jaminan. Harga tanah yang cenderung naik dari tahun ke tahun yang dikarenakan jumlah tanah yang terbatas sedangkan permintaan akan tanah semakin tinggi karena semakin bertambahnya jumlah penduduk dan penentu harga bukanlah pasar tetapi orang (pihak) yang menguasai tanah tersebut membuat industri property dan real estate ini semakin banyak disukai oleh investor ataupun kreditor. Industri property dan real estate yang terdaftar di BEI mengalami peningkatan dari 40 perusahaan pada tahun 2010 menjadi 49 perusahaan ditahun 2016, sedangkan di tahun 2017 jumlahnya turun menjadi 47 perusahaan dikarenakan terdapat dua perusahaan delisting karena merger dengan perusahaan lain (www.sahamok.com, 2017).

\section{TINJAUAN PUSTAKA}

Manajemen keuangan atau sering disebut pembelanjaan dapat diartikan sebagai semua aktivitas perusahaan yang berhubungan dengan usaha-usahan mendapatkan dana perusahaan dengan biaya yang murah serta usaha menggunakan dan mengalokasikan dana tersebut secara efisien.(Sutrisno, 2000). Manajemen kauangan (financial manajemen) adalah segala aktivitas perusahaan yang berhubungan dengan memperoleh dana. Memperoleh dan mengelola asset sebagai tujuan perusahaan secara menyeluruh . Dengan kata lain berarti manajemen keuangan 
merupakan manajemen (pengelolaan). (Hertono dan Agus, 2005).

Likuiditas merupakan kemampuan perusahaan untuk membayar kemampuan finansial jangka pendek tepat pada waktunya, likuiditas perusahaan ditujukan oleh besar kecilnya aktiva lancar yaitu aktiva yang mudah untuk diubah menjadi kas yang meliputi kas, surat berharga, piutang dan persediaan (Sartono, 2010:116).

Current Ratio (CR), adalah rasio yang digunakan untuk mengukur kemampuan perusahaan dalam membayar kewajiban jangka pendeknya pada saat ditagih secara keseluruhan. Untuk mengukur Current Ratio mengacu pada penelitian (Ambarwati,2015). Rumusnya sebagai berikut:

$$
\text { Current Ratio }=\frac{\text { Aktiva lancar }}{\text { Utang lancar }}
$$

Wiagustini (2010:76) menyatakan profitabilitas merupakan suatu kemampuan perusahaan untuk mewujudkan suatu keuntungan bagi perusahaan atau merupakan suatu pengukuran akan efektivitas pengelolaan perusahaan dalam mengelola manjemennya.

Return On Asset (ROA), merupakan kemampuan perusahaan dengan menggunkan seluruh aktiva yang dimiliki untuk menghasilkan laba setelah pajak (Sudana, 2009:24). ROA yang semakin meningkat menunjukkan bahwa kinerja keuangan juga akan meningkat. Rumus ROA adalah sebagai berikut:

$$
\text { Return On Asset }=\frac{\text { Laba bersih setelah pajak }}{\text { Total asset }}
$$

Menurut Jumingan (2006:239), kinerja keuangan merupakan gambaran suatu kondisi keuangan perusahaan pada periode tertentu, baik menyangkut aspek penghimpun dana maupun penyaluran dana yang biasanya diukur dengan indikator kecukupan modal, profitabilitas, dan likuiditas. Menurut (Sutrisno, 2009:53).

Gross Profit Margin (GPM), merupakan perbandingan anatara laba kotor yang diperoleh perusahaan dengan tingkat penjulana yang diacapai pada periode yang sama. GPM merupakan kemampuan efisiensi produksi dan kemampuan penjulan (Mamduh \& Halim, 2009:83) Jika nilai GPM perusahaan besar maka dapat disimpulkan bahwa perusahaan mendapatkan laba kotor yang besar dibandingkan dengan penjualannya. Oleh karena itu, semakin tinggi laba kotor maka semakin tinggi Gross Profit Margin yang dapat dihasilkan. GPM dapat dirumuskan sebagai berikut:

Gross profit margin $=\frac{\text { Laba Kotor }}{\text { Penjwalan Bersih }} \mathrm{X}$ $100 \%$

\section{METODE PENELITIAN}

Berdasarkan jenisnya, penelitian ini tergolong dalam pendekatan kuantitatif yang menggunakan angka-angka sebagai data penelitian, pendekatan dalam penelitian ini adalah pendekatan cross sectional (pengamatan sesaat) atau penelitian dengan melakukan pengukuran atau pengamatan pada saat bersamaan atau sekali waktu (Hidayat, 2007 dalam kusumo wardani, 2014).

Metode analisis dalam penelitian ini melalui uji statistic deskriptif variable, uji asumsi klasik, uji koefisien determinasi, uji koefisien korelasi, uji regresi moderasi, uji kelayakan model (uji-F) dan uji regresi parsial (uji-t). Pengujian dilakukan melalui SPSS versi 22.

Berdasarkan metode analisis tersebut, Hipotesis yang akan di uji yaitu:

$\mathrm{H}_{1} \quad$ : Likuiditas berpengaruh terhadap Kinerja Keuangan.

$\mathrm{H}_{2} \quad$ : Profitabilitas memoderasi pengaruh Likuiditas terhadap Kinerja Keuangan.

\section{HASIL DAN PEMBAHASAN}

Pengujian pertama yang dilakukan yaitu uji normalitas, dengan uji statistic nonparametik Kolmogorov-Smirnov (K-S). hasil pengujian adalah sebagai berikut:

\section{Tabel 1}

\section{Uji Normalitas}

\begin{tabular}{|c|c|c|}
\hline \multirow{2}{*}{$\mathrm{N}$} & & $\begin{array}{l}\text { Unstandardized } \\
\text { Residual }\end{array}$ \\
\hline & & 48 \\
\hline \multirow{2}{*}{$\begin{array}{l}\text { Normal } \\
\text { Parameters }{ }^{\mathrm{a}, \mathrm{b}}\end{array}$} & Mean & .0000000 \\
\hline & Std. Deviation & 8.42701171 \\
\hline \multirow{3}{*}{$\begin{array}{l}\text { Most Extreme } \\
\text { Differences }\end{array}$} & Absolute & .113 \\
\hline & Positive & .113 \\
\hline & Negative & -.081 \\
\hline
\end{tabular}

One-Sample Kolmogorov-Smirnov Test 
Test Statistic

Asymp. Sig. (2-tailed)

$.160^{\mathrm{c}}$

a. Test distribution is Normal.

b. Calculated from data.

c. Lilliefors Significance Correction.

Berdasarkan table diatas, nilai Asymp.Sig.(2-tailed) yaitu 0.160, dan kriteria yang di tetapkan adalah nilai Asymp.Sig.(2-tailed) $>0.05$. Maka dapat dapat disimpulkan bahwa dalam penelitian ini terdistribusi normal.

Pengujian kedua yang dilakukan adalah uji Autokorelasi dengan melalui uji Durbin-Watson. Hasil pengujian sebagai berikut:

\section{Tabel 2 \\ Uji Autokorelasi}

Berdasarkan table diatas, nilai DW sebesar 2.062. Jumlah responden dalam penelitian ini yaitu 48 dan 1 variabel $\mathrm{x}$ maka diperoleh nilai dL sebesar 1.4928, nilai dU sebesar 1.5776 dan nilai 4-dU sebesar 2.4224 dan jika dimasukkan dalam kriteria DW maka perbandingannya $\mathrm{Du}<\mathrm{d}<4$-du maka 1.5776<2.062<2.4224. Maka dapat disimpulkan dalam penelitian ini tidak terdapat Autokorelasi.

Pengujian ketiga yaitu uji Multikolonieritas, melalui nilai Tolerance dan Variance Inflation Factor (VIF) . nilai VIF berada dibawah 10 dan nilai tolerance mendekati 1. Hasil pengujian sebagai berikut:

Tabel 3

Uji Multikolonieritas

\begin{tabular}{|c|c|c|c|}
\hline \multicolumn{4}{|c|}{ Coefficients $^{\mathrm{a}}$} \\
\hline & & \multicolumn{2}{|c|}{ Collinearity Statistics } \\
\hline \multicolumn{2}{|c|}{ Model } & Tolerance & VIF \\
\hline $1 \quad$ & (Constant) & & \\
\hline & $\mathrm{X}$ & .192 & 5.219 \\
\hline & M & .611 & 1.637 \\
\hline & $\mathrm{X} * \mathrm{M}$ & .205 & 4.871 \\
\hline
\end{tabular}

Dependent Variable: Y

Berdasarkan table diatas nilai Tolerance mendekati 1 dan nilai VIF dibawah 10, maka dapat disimpulkan dalam penelitian ini tidak terjadi Multikolonieritas.

Pengujian keempat yaitu uji Heterokesdastisitas, Hasil pengujian sebagai berikut:
Tabel 4

Uji Heterokesdastisitas

Coefficients $^{\mathrm{a}}$

\begin{tabular}{llrr}
\multicolumn{2}{c}{ Model } & \multicolumn{2}{c}{ Sig. } \\
\hline 1 & (Constant) & 3.594 & .001 \\
& $\mathrm{X}$ & -1.368 & .178 \\
$\mathrm{M}$ & .385 & .702 \\
& $\mathrm{X}$ & & \\
& & .650 & .519
\end{tabular}

a. Dependent Variable: Hetero

Berdasarkan table diatas menunjukkan nilai Sig. > 0.05 pada masing-masing variable maka dapat disimpulkan bahwa dalam penelitian ini tidak terjadi Heterokesdastisitas.

Pengujian kelima dan keenam yaitu uji regresi moderasi, Hasil pengujian sebagai berikut:

\section{Tabel 5}

Uji Regresi Moderasi (MRA)

Berdasarkan table diatas Nilai koefisien regresi CR (X) sebesar -0.783, artinya jika CR meningkat sebesar 1 satuan maka kinerja

\begin{tabular}{|c|c|c|c|}
\hline \multicolumn{4}{|c|}{ Model Summary } \\
\hline & \multicolumn{3}{|c|}{ Change Statistics } \\
\hline Model & $\mathrm{df} 2$ & $\begin{array}{c}\text { Sig. F } \\
\text { Change }\end{array}$ & Durbin-Watson \\
\hline 1 & 44 & .000 & 2.062 \\
\hline
\end{tabular}
dengan asumsi variable independent lainnya konstan. Nilai koefisien regresi ROA (M) sebesar 1.067, artinya jika ROA meningkat sebesar 1 satuan maka kinerja keuangan (Y) akan meningkat sebesar 1.067 dengan asumsi variable independent lainnya konstan. Nilai koefisien regresi interaski antara $\mathrm{CR}(\mathrm{X})$ dengan $\operatorname{ROA}(\mathrm{M})$ sebesar 0.181 , artinya jika interaksi antara CR dengan ROA meningkat sebebsar 1 satuan maka kinerja keuangan (Y) akan meningkat sebesar 0.181 dengan asumsi variable independent lainnya konstan.

Berikut adalah table kontribusi variable indenden terhadap variable dependen. 
Tabel 6

Kontribusi variable independent terhadap variable dependent

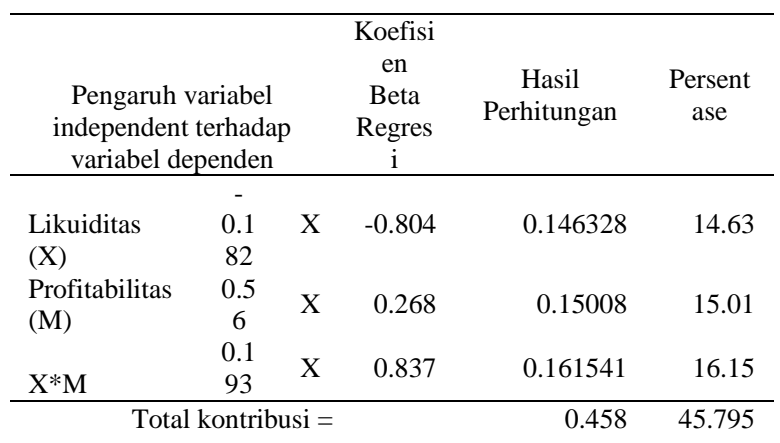

Berdasarkan table diatas besaran kontribusi variable $\mathrm{X}$ dari hasil perkalian koefisien regresi dikalikan dengan nilai korelasi terhadap variable Y sebesar 0.146328 atau $14.63 \%$. Besaran kontribusi variable $M$ dari hasil perkalian koefisien regresi dikalikan dengan nilai korelasi terhadap variable $\mathrm{Y}$ sebesar 0.15008 atau $15.01 \%$, sedangkan besaran kontirbusi variabel moderasi $\left(\mathrm{X}^{*} \mathrm{M}\right)$ terhadap Y sebesar 0.161541 atau $16.15 \%$.

Berdasarkan hasil tersebut dapat disimpulkan bahwa variable interaksi antara $\mathrm{X}^{*} \mathrm{M}$ memiliki pengaruh lebih tinggi dibandingkan variable lainnya yaitu Current Ratio (X) dan Return On Asset (M) Hal itu disebabkan besaran kontribusi yang diberikan terhadap kinerja keuangan(Y) sebesar $16.15 \%$ yang lebih besar dibandingkan dengan besaran kontribusi variable independen. Artinya, dalam penelitian ini variable $\mathrm{CR}(\mathrm{X})$ tidak efektif jika pengaruhnya langsung ke variable kinerja keuangan (Y). tetapi dengan adanya variable moderasi maka akan memberikan kontribusi yang lebih terhadap terjadinya kenaikan yang tinggi pada kinerja keuangan perusahaan yang dilihat dari perbandingan nilai kontribusinya.

Pengujian ke tujuh yaitu uji kelayakan model(uji-F), dengan kriteria nilai Sig. $<0.05$ maka model dinyatakan layak untuk dianalisis lebih lanjut. Hasil uji-F sebagai berikut:
Tabel 7

Uji-F

\begin{tabular}{|c|c|c|c|c|c|c|}
\hline \multicolumn{7}{|c|}{$\mathbf{A N O V A}^{\mathrm{a}}$} \\
\hline \multicolumn{2}{|c|}{ Model } & $\begin{array}{l}\text { Sum of } \\
\text { Squares }\end{array}$ & Df & $\begin{array}{c}\text { Mean } \\
\text { Square }\end{array}$ & $\mathrm{F}$ & Sig. \\
\hline 1 & Regression & 2819.640 & 3 & 939.880 & 12.390 & $.000^{\mathrm{b}}$ \\
\hline & Residual & 3337.683 & 44 & 75.856 & & \\
\hline & Total & 6157.322 & 47 & & & \\
\hline
\end{tabular}

a. Dependent Variable: Y

b. Predictors: (Constant), X*M, M, X

Berdasarkan table diatas menunjukkan nilai Sig. 0.000, dan apabila dimasukkan dalam kriteria yang ada maka $0.000<0.05$, maka dapat disimpulkan bahwa Ha diterima model yang disusun oleh peneliti memenuhi kriteria kelayakan model. Variable independen dalam penelitian ini secara simultan berpengaruh terhadap kinerja keuangan.

Pengujian ke delapan dan kesembilan adalah Uji koefisien parsial (uji-t), dengan kriteria $\mathrm{H}_{1}$ : t-hitung > t-tabel : maka $\mathrm{HO}$ di tolak dan Ha diterima, Hipotesis penelitian diterima.

$\mathrm{H}_{2}$ : t-hitung < t-tabel : maka H0 diterima dan Ha di tolak, hipotesis penelitian ditolak.

Dan Nilai sig. $<0.05$. Hasil uji-t sebagai berikut:

Tabel 8

Uji-t

\begin{tabular}{|c|c|c|c|c|c|c|}
\hline \multicolumn{7}{|c|}{ Coefficients $^{a}$} \\
\hline & Model & \multicolumn{2}{|c|}{$\begin{array}{c}\text { Unstandardized } \\
\text { Coefficients } \\
\text { Std. }\end{array}$} & $\begin{array}{c}\text { Standardized } \\
\text { Coefficients } \\
\text { Beta }\end{array}$ & $\mathrm{t}$ & Sig. \\
\hline 1 & (Constant) & 20.153 & 3.518 & & 5.729 & .000 \\
\hline & $\mathrm{X}$ & -.783 & .247 & -.804 & -3.170 & .003 \\
\hline & $\mathrm{M}$ & 1.067 & .565 & .268 & 1.887 & .066 \\
\hline & $\mathrm{X}^{*} \mathrm{M}$ & .181 & .053 & .837 & 3.415 & .001 \\
\hline
\end{tabular}

Berdasarkan table diatas jika dimasukkan dalam kriteria yang ada, maka dapat disimpulkan bahwa :

$\mathrm{H}_{1}:-3.170<2.015$ dan nilai sig. $0.003<$ 0.05 maka $\mathrm{H}_{0}$ diterima dan $\mathrm{H}_{1}$ ditolak, maka hipotesis dalam penelitian ini di tolak. Maka dapat disimpulkan bahwa Likuiditas berpengaruh negative dan signifikan terhadap kinerja keuangan. Artinya, jika Likuiditas rendah maka kinerja keuangan juga akan 
rendah. Hasil penelitian ini sejalan dengan penelitian yang dilakukan oleh Nademm, dkk (2014) dan Krisdasusila \& Rachmawati (2016) bahwa secara parsial Current Ratio (CR) berpengaruh negative dan signifikan terhadap Kinerja keuangan.

$\mathrm{H}_{2}$ : $3.415>2.015$ dan nilai sig. $0.001>$ 0.05 maka $\mathrm{H}_{0}$ ditolak dan $\mathrm{H}_{2}$ diterima, maka hipotesis dalam penelitian ini diterima. Maka dapat disimpulkan bahwa Likuiditas dimoderasi Profitabilitas berpengaruh positif dan signifikan terhadap kinerja keuangan, Artinya Profitablitas mampu memoderasi Likuiditas terhadap Kinerja keuangan.

\section{KESIMPULAN DAN SARAN}

1. Berdasarkan pengujian Hipotesis mengenai Pengaruh Likuiditas terhadap kinerja keuangan dapat disimpulkan bahwa Likuditas berpengaruh negative dan signifikan terhadap kinerja keuangan. Hasil penelitian ini sejalan dengan penelitian yang dilakukan oleh Rachmawati (2016). Hal ini mengindikasikan bahwa rendahnya current ratio dapat dianggap menunjukkan terjadinya masalah dalam likuiditas. Namun current ratio-nya terlalu tinggi juga tidak bagus karena menunjukkan banyaknya dana yang menganggur. Selain itu, Hasil penelitian ini mengindikasi bahwa $\mathrm{CR}$ tidak mampu memberikan kontribusi yang kuat terhadap Kinerja keuangan perusahaan sub sector Property \& Real estate yang terdaftar di Bursa Efek Indonesia.

2. Berdasarkan pengujian Hipotesis mengenai pengaruh Profitabilitas terhadap kinerja keuangan dapat disimpulkan bahwa Profitabilitas berpengaruh Positif dan signifikan terhadap kinerja keuangan. Hasil penelitian ini sejalan dengan penelitian yang dilakukan oleh Lusi mirnawati, Lestari wuryanti dan Bambang purwanto (2015). Artinya, dalam penelitian ini variable $\mathrm{CR}(\mathrm{X})$ tidak boleh langsung ke variable kinerja keuangan (Y) tetapi dengan adanya variable ROA(M) sebagai variable pemoderasi maka akan memberikan kontribusi yang lebih terhadap terjadinya kenaikan yang tinggi pada kinerja keuangan perusahaan yang dilihat dari perbandingan nilai kontribusinya. Hal ini menunjukkan bahwa dengan adanya variable Moderasi maka dapat memperkuat pengaruh Likuiditas terhadap kinerja Keuangan pada perusahaan Property \& real estate yang terdaftar di Bursa Efek Indonesia.

\section{REFERENSI}

Azis, A. (2017). Pengaruh Good Corporate Governance, Struktur Modal, dan Leverage Terhadap Kinerja Keuangan Perusahaan Pada Sektor Pertambangan yang Terdaftar di Bursa Efek Indonesia Tahun 2011-2015. Jurnal Ilmu Manajemen (JIM), 5(3).

Dj, A. M., Artini, L. G. S., \& Suarjaya, A. G. (2012). Pengaruh kinerja keuangan terhadap nilai perusahaan pada perusahaan manufaktur di Bursa Efek Indonesia. Matrik: Jurnal Manajemen, Strategi Bisnis dan Kewirausahaan.

Hasanah, I., Susyanti, J., \& Wahono, B. (2017). Analisis Kinerja Keuangan Perusahaan Real Estate Dan Property Yang Terdaftar Di Bursa Efek Indonesia Sebelum Dan Selama Pemerintahan Presiden Jokowi. Jurnal Warta Ekonomi, 6(01).

Mery, K. N., \& Kurnia, P. (2017). Pengaruh Likuiditas, Leverage Dan Profitabilitas Terhadap Nilai Perusahaan Dengan Kebijakan Dividen Sebagai Variabel Moderasi Pada Perusahaan Pertambangan Yang Terdaftar Di Bursa Efek Indonesia Tahun 2011-2014. Jurnal Online Mahasiswa Fakultas Ekonomi Universitas Riau, 4(1), 2000-2014.

Sari, K. D. C., Azhari, M., \& Dewi, A. S. (2016). Pengaruh Profitabilitas, Leverage, Likuiditas, dan ukuran Perusahaan Terhadap Ketepatan Pengungkapan Laporan Keuangan Pada Perusahaan Sub Sektor Properti dan Real Estate Yang Terdaftar di Bursa Efek Indonesia periode 2011-2014. eProceedings of Management, 3(1).

Alamsyah, S. (2017). Pengaruh Profitabilitas Terhadap Nilai Perusahaan, Relevansi Nilai Informasi Akuntansi, Keputusan Investasi, Kebijakan Dividen Sebagai Variabel Intervening (Studi Empiris Pada Perusahaan Indeks Kompas 100 Periode 2010-2013). Competitive Jurnal Akuntansi dan Keuangan, 1(1), 136-161.

Puspitaningtias, S., \& Sampurno, R. D. (2018). Analisis pengaruh Current Ratio ,Debt To Equity Ratio, Working Capital Turnover, Asset Tangibility, Total Asset Turnover, dan Asset Growth terhadap Kinerja Keuangan (Studi Kasus Pada Perusahaan Manufaktur yang Terdaftar 
di Bursa Efek Indonesia Tahun 20122016) (Doctoral dissertation, Fakultas Ekonomika dan Bisnis).

Pangkong, C. M., Lambey, L., \& Afandi, D. (2017). Dampak Rasio Aktivitas Dan Rasio Likuiditas Terhadap Perubahan Laba Berbasis Fair Value (Studi Empiris Pada Perusahaan Sub Sektor Property Dan Real Estate Yang Terdaftar Di Bursa Efek Indonesia). Jurnal EMBA: Jurnal Riset Ekonomi, Manajemen, Bisnis dan Akuntansi, 5(2).

Febrianty, F., \& Wulandari, W. Kinerja Keuangan Perusahaan Property dan Real Estate di BEI Selama Periode 2012-2016 yang Termasuk di Indeks LQ45 (Studi pada Perusahaan yang Termasuk Pemeringkatan Indeks LQ45 Periode Februari 2017-Juli 2017). Jurnal Manajemen dan Bisnis Sriwijaya, 15(1), 1-12.

Ramadhana, A. A., \& Sjahruddin, H. (2018). Pengaruh Kinerja Keuangan Terhadap Harga Saham.

Fatimah, F., Mardani, R. M., \& Wahono, B. (2019). Pengaruh Good Corporate Governance Terhadap Nilai Perusahaan dengan Kinerja Keuangan Sebagai Variabel Intervening (Studi Kasus Pada Perusahaan Manufaktur Sektor Barang. Jurnal Ilmiah Riset Manajemen, 8(15).

Bionda, A. R., \& Mahdar, N. M. (2017). Pengaruh Gross Profit Margin, Net Profit Margin, Return On Asset, dan Return On Equity Terhadap Pertumbuhan Laba Pada Perusahaan Manufaktur di Bursa Efek INdonesia. Jurnal Bisnis dan Komunikasi, 2356-4385.

Sawitri, N. M. Y., Wahyuni, M. A., Yuniarta, G. A., \& AK, S. (2017). Pengaruh Kinerja Keuangan , Ukuran Perusahaan, dan Struktur Kepemilikan Terhadap Profitabilitas (Studi Empiris Pada Perusahaan Property dan Real Estate Yang Terdaftar Di Bursa Efek Indonesia (BEI) Periode Tahun 2012-2015). JIMAT (Jurnal Ilmiah Mahasiswa Akuntansi) Undiksha, 7(1).

Primantara, A. N. A. D. Y., \& Dewi, M. R. (2016). Pengaruh Likuiditas, Profitabilitas, Risiko Bisnis, Ukuran Perusahaan, Dan Pajak Terhadap Struktur Modal. E-Jurnal Manajemen, 5(5).

Mardiyati, U., Ahmad, G. N., \& Putri, R.
(2012). Pengaruh kebijakan dividen, kebijakan hutang dan profitabilitas terhadap nilai perusahaan manufaktur yang terdaftar di Bursa Efek Indonesia (BEI) periode 2005-2010. JRMSI-Jurnal Riset Manajemen Sains Indonesia, 3(1), 1-17.

Feri, M. (2015). Pengaruh Rasio Profitabilitas Terhadap Perubahan Harga Saham Pada Perusahaan Sektor Properti Yang Listing di Bursa Efek Indonesia Periode 20082012. Jurnal Ilmu Manajemen (JIM), 2(4).

Oktiar, T. (2014). Pengaruh Debt To Equity Ratio, Return On Equity, Tingkat Suku Bunga, Dan Inflasi Terhadap Return Saham Perusahaan Subsektor Property Dan Real Estate Yang Terdaftar Di Bursa Efek Indonesia Periode 2007-2012. Jurnal Akuntansi, 2(2), 80-93.

Hadianto, M. L., \& WAHYUDI, S. (2013). Analisis Pengaruh Kinerja Keuangan terhadap Nilai Perusahaan dengan Pengungkapan CSR dan GCG sebagai Variabel Pemoderasi (Studi Empiris pada Perusahaan Consumer Goods yang Terdaftar di Bursa Efek Indonesia 20082011) (Doctoral dissertation, Fakultas Ekonomika dan Bisnis).

Pratama, I. G. G. W., \& Wirawati, N. G. P. (2016). Pengaruh struktur modal dan profitabilitas terhadap nilai perusahaan dengan kepemilikan manajerial sebagai pemoderasi. E-Jurnal Akuntansi, 17961825. 